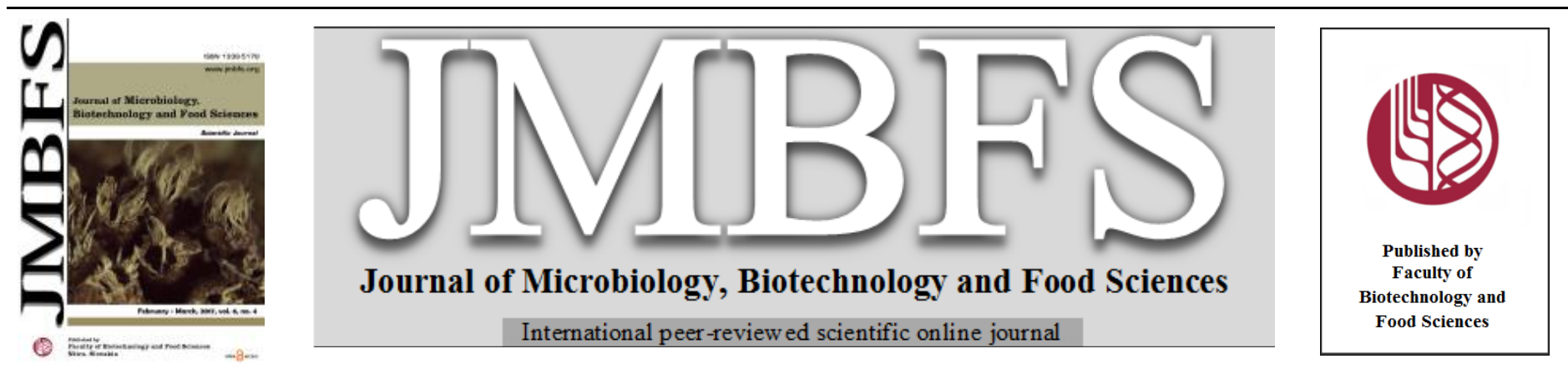

\title{
BIOLOGICAL ASPECTS OF ANAEROBIC DIGESTION AND ITS KINETICS: AN OVERVIEW
}

\section{Prathaban Munisamy, Mythili Ravichandran, Sharmila Devi Natarajan, Chandrasekar Varadhaaraju *}

Address(es):

PG and Research Department of Microbiology, K S Rangasamy College of Arts and Science, Tiruchengode - 637215, Tamilnadu, India.

*Corresponding author: vchandrasekar@yahoo.com

doi: 10.15414/jmbfs.2017.6.4.1090-1097

\section{ARTICLE INFO}

Received 28. 9. 2015

Revised 26. 4. 2016

Accepted 18. 12. 2016

Published 1. 2. 2017

\section{Review}

OPEN $\odot$ ACcESS

\begin{abstract}
Anaerobic digestion is an anoxic microbiological process occurring in natural environments. Though, the process is considered to be the oldest, its concept relies on the fourth generation biofuel for direct sequestration of carbon-di-oxide into methane. However, the process is successful in natural environments in the efficiency of methane yield with compared to pilot or industrial scale. An overview of an anaerobic digestion and its kinetics is detailed in this review for the successful digestion process, which includes microbiological process, methanogenic interactions, operational conditions of the digester, substrate requirements and its limitation, substrate enhancement by pretreatment and co-digestion process and other rate limiting parameters affecting the process in order to increase the efficiency of methane production.
\end{abstract}

Keywords: Anaerobic digestion, co-digestion, anoxic, methane, biomethanation, kinetics

\section{INTRODUCTION}

The increasing world's population and economical growth in the recent years visualize a dramatic impact over the environment. The augmented anthropogenic activities have developed the crisis in various aspects such as global warming, global energy demand, management of accumulated solid wastes, etc. The anaerobic digestion $(\mathrm{AD})$ process will be a single step solution for this crisis. This process can be achieved in various climatic ranges starting from phsycrophilic to thermophilic. AD is a series of natural process in which the biological waste or organic materials are converted into energy in the form of "Biogas" (a mixture of Methane and $\mathrm{CO}_{2}$ ) and the "Digestate" or "Effluent" $\left(\mathrm{N}_{2}\right.$ rich product) in the absence of $\mathrm{O}_{2}$. The production of methane which can serve as the part of energy constraints makes $\mathrm{AD}$ process more advantages over aerobic process, which also reduces the excess of sludge production and feasible recovery of useful products; e.g., $\mathrm{NH}_{3}$ and sulphur (Bolzonella et al., 2005). This method of digestion uses wide range of bio-materials like livestock manure, agricultural waste, house hold waste, municipal waste water solids, food waste, high strength industrial wastes and residuals, fats, oils and grease (FOG) and convert a mixture of organic substrates into biogas and other valuable products. Biogas can be directly combusted to generate heat for cooking (Domestic use), or to generate electricity, or can be processed into renewable fuel for transportation (http://www.americanbiogascouncil.org, Department for Environment and Rural Affairs, 2011). The digestate which is rich in nitrogen source can be directly applied to agricultural fields as biological fertilizer or as soil conditioners. Particularly the liquid and solid materials are highly pliable to this process.

\section{Microbial Archetypes}

The archetypal of anaerobic digestion lies vitally within the four stages of biological and chemical process that interpolates Hydrolysis (heterogenous reaction), Acidogenesis, Acetogenesis and Methanogenesis and the conversion is actualized by five groups of microorganisms (Chandrasekar, 2004).

Group 1
Group 2
bacteria
Group 3
Group 4
Group 5

Hydrolytic Fermentative bacteria

Obligate hydrogen producing acetogenic

Oxidizing acetogenic bacteria

Carbon dioxide reducing methanogens and

Aceticlastic methanogens

\section{Hydrolysis and Acidogenesis}

The anaerobic digestion process begins with the bacterial hydrolysis of the complex biodegradable polymers (polysaccharides) into soluble form (simple sugars) and make them available for other bacteria (stage 1), which is acquired by group 1 hydrolytic fermentative bacteria. The fermentative hydrolytic bacteria contain the complex consortium of many bacterial species (Bryant 1979). Many of these species are obligate anaerobes and a few facultative anaerobes such as Enteric bacteria, Streptococci were also present (Archer, 1983). Anaerobic bacteria belonging to diverse genera such as Bacteroides, Bifidobacterum, Butyrivibrio, Clostridium, Eubacterium, Ruminococcus etc., are predominant in anaerobic digester and rumen (Chandrasekar, 2004).

The hydrolysis process is mainly accomplished by extracellular enzymes. The hydrolysis of a complex and insoluble substrates depend on different parameters such as particle size, $\mathrm{pH}$, production, diffusion and adsorption of enzymes to particles. The various hydrolysis rates for different substrates are $0.025-0.200 \mathrm{~d}^{-1}$ for carbohydrates, $0.040-0.130 \mathrm{~d}^{-1}$ for cellulose, $0.005-0.010 \mathrm{~d}^{-1}$ for lipids (Wilderer et al., 2000), food wastes mixtures $0.40 \mathrm{~d}^{-1}$ and solid wastes mixtures $0.012 \mathrm{pH}-0.042$ (Kalyuzhnyi et al., 1999). Cellulose is hydrolysed into glucose which is converted into pyruvate by EMP pathway, which is, in turn, fermented into acetate, hydrogen, carbon dioxide or ethanol, lactate, succinate, propionate, and butyrate depending upon low and high partial pressure of hydrogen respectively (Chandrasekar, 2004). Hemicellullose is primarily degraded into pentosans and then to pentoses, mainly cellulose, which is further fermented into lactate, succinate, acetate, propionate, butyrate, hydrogen and carbon-di-oxide. Starch degradation rate is rapid with compared to cellulose and hemicelluloses degradation. It is hydrolysed into glucose which is then fermented (Nagarwala, 1987). Degradation of natural lignin is slow and partial compared with other substrate, but the monomers and oligomers of lignin are comparatively and readily metabolized (Young and Frazer, 1987). Pectins are hydrolysed into pectic acid and methanol, then the pectic acid is initially fermented into galacturonic acid and then into hydrogen and carbon dioxide (Bernhad, 2006).

Hydrolysis of cellulose is carried out by Clostridium thermocellum, Clostridium stercorarium, Clostridium cellulofementans, Clostridium lentocellum, Clostridium papyrosolvens, Clostridium cellulolyticum, Clostridium joseii, Acetovibrio cellulolyticus, Bacteroides cellulosolvens, Clostridium aldrichii, Clostridium celerecrescens, Clostridium cellulovorans, Ruminococcus flacefaciens, Ruminococcus albus and Clostridium popueii reported by Leschine (1995).

In 1982, Theather \& Wood reported the hydrolysis of cellulose by Bacteroides fibrisolvens, Clostridium cellulobioparum, Ruminococcus flavefaciens, Bacteroides succinogenes, Eubacterium cellulosolvens. Hydrolysis of suspended 
organic solid was reported by Clostridium thermopalmarium and Clostridium novyi was recorded by Man et al. 2010. Hydrolysis is generally the rate limiting step in the overall anaerobic digestion process. It is considered as the first order kinetics (Eqn.1) with respect to the biodegradable solids. The individual rates of the succeeding conversion processes generally fit Monod kinetics as shown in equation 2 (Buswell et al., 1995).

\section{$-\mathrm{dF} / \mathrm{dt}=\mathrm{K}_{\mathrm{h}} \mathrm{F}$}

Where, $\mathrm{F}=$ concentration of insoluble substrate, $\mathrm{M} . \mathrm{L}^{-3}$

$\mathrm{K}_{\mathrm{h}}=$ first order hydrolysis rate constant, $\theta^{-1}$

$\mathrm{T}=$ time, $\theta^{-1}$

$\mu=\mu_{\mathrm{m}} \mathrm{S} /\left(\mathrm{K}_{\mathrm{s}}+\mathrm{S}\right)-\mathrm{b} ; \quad-\mathrm{dS} / \mathrm{dt}=\mathrm{X} \mu_{\mathrm{m}} / \mathrm{Y}$

Where, $\mu$ is the specific growth rate of microorganism, $\theta^{-1}$

$\mu_{\mathrm{m}}$ is the maximum specific growth rate of microorganism, $\theta^{-1}$

$\mathrm{K}_{\mathrm{s}}$ is the half saturation constant, M.L ${ }^{-3}$

$\mathrm{S}$ is the substrate concentration, $\mathrm{M} . \mathrm{L}^{-3}$

$\mathrm{X}$ is the microorganism concentration, $\mathrm{M} . \mathrm{L}^{-3}$

$\mathrm{Y}$ is the growth yield coefficient M.M ${ }^{-1}$

$\mathrm{B}$ is the specific decay rate of microorganism, $\theta^{-1}$

$\theta, \mathrm{M}, \mathrm{L}^{3}$ is the units of time, mass, and volume respectively.

There are many anaerobic fermentation pathways, but the multifarious group of fermentative anaerobes mostly use lactic acid pathway. Anaerobic bacteria and arachea also use lactic acid pathway and other fermentation pathways including propionic acid fermentation pathway, butyric acid fermentation pathway, stickland fermentation pathway, mixed acid fermentation pathway and solvent fermentation (Stage 2).

The proteins are initially hydrolysed into peptide and then into amino acids by proteolytic anaerobic microorganism. Then these amino acids are decarboxylated and deaminated into organic acids and other products (Ramsay and Pullamanappallil, 2001). The branched amino acids such as valine, leucine and isoleucine are fermented into iso-butyrate, iso-valate and D-2-methyl butyrate respectively. Aromatic amino acids such as phenylalanine, tyrosine and tryptophan are metabolized into phenyl-acetic acid, phenyl-propionic acid, indole, etc., (Elsden et al., 1976).

Lipids are hydrolysed into long chain fatty acids like palmitic acid, stearic acid and glycerol and they are fermented into volatile fatty acids, hydrogen and carbon-di-oxide (Mackie et al., 1991). The short chain fatty acids are converted (other than acetate) into acetate, hydrogen and carbon dioxide (Angelidaki et al. 2011). Unsaturated fatty acids like oleic, linoleic and linolenic acid are hydrogenated into stearic acid. The products such as organic acids, volatile acids, acetate, long chain fatty acids, alcohol, ammonia, hydrogen, sulphur, formate and other fermentative products like lactate, sucinate, butyrate etc. are formed during fermentative cycle. (Mclnemy and Bryant, 1981).

\section{Acetogenesis}

Acetogens are obligatory anaerobic bacteria which uses the reductive acetyl-CoA or Wood-Ljungdahl pathway (Fig.1.0) as their main mechanism for energy conservation and for the synthesis of Acetyl-CoA and cell carbon from $\mathrm{CO}_{2}$. Acetogens are able to convert $\mathrm{H}_{2}$ and $\mathrm{CO}_{2}$ into Acetic acid. They are strict anaerobic bacteria that can grow by the conversion of $\mathrm{C}_{1}$ compound such as $\mathrm{H}_{2}$ $\mathrm{CO}_{2}, \mathrm{CO}$ and formate into acetate (Diekert and Wohlfahrt 1994). The various substrates such as butyric acid, lactate, acetone, butanol, propionate etc., are converted into acetate, formate, $\mathrm{CO}_{2}$ and $\mathrm{H}_{2}$. Acetogens grow on various substrates such as hexoses, $\mathrm{C}_{2}$ and $\mathrm{C}_{1}$ compounds. Hexoses are converted exclusively into acetate and therefore, this fermentation is also referred to as homoacetogenesis (Eqn.3) (Volker, 2003).

$$
\mathrm{C}_{6} \mathrm{H}_{12} \mathrm{O}_{6} \longrightarrow \quad 3 \mathrm{CH}_{3} \mathrm{COOH}
$$

The acetogenic group further decomposes higher volatile fatty acids into acetate and $\mathrm{H}_{2}$, which are utilized as substrates for the growth and metabolism of methanogenic bacteria (Ferry and Lessner, 2008). Acetogens also successfully coexist with sulphate reducers and methanogens for various reasons. These include (1) to yield energy from wide and various range of acetogenic reactions, (2) wide range of substrate that enables various types of niche and/or gains energy from a wide range of various substrates, and (3) lesser energetic cost of biosynthesis among acetogens due to the use of reductive acetyl-CoA pathway for both energy production and biosynthesis coupled with the ability to use many organic precursors to produce key intermediate acetyl-CoA (Mark, 2012).

The precursor to the acetic acid is the trimester acetyl-CoA. The key aspect of acetogenic pathway consists of several reactions including the reduction of carbon-di-oxide into carbon monoxide and the attachment of carbon monoxide to a methyl group. The first process is catalyzed by the enzyme carbon monoxide dehydrogenase (Eqn.4). The coupling of methyl group (provided by methylcobalamine) and CO is catalyzed by acetyl-CoA synthetase. In 1936, Wieeringa reported the first acetogenic bacterium Clostridium aceticum, and Moorella thermoacetica. A clostridium in the Thermoanaerobacteriaceae family has attained wide interest because of its unusual ability to convert glucose almost stoichiometrically into three moles of acetic acid (Eqn.5) (Ragsdale and Pierce, 2008).

$$
2 \mathrm{CO}_{2}+4 \mathrm{H} 2=\mathrm{CH}_{3} \mathrm{COO}^{-}+\mathrm{H}^{+}+2 \mathrm{H}_{2} \mathrm{O} \triangle \mathrm{G}^{0}=-95 \mathrm{KJ} / \mathrm{mol}
$$

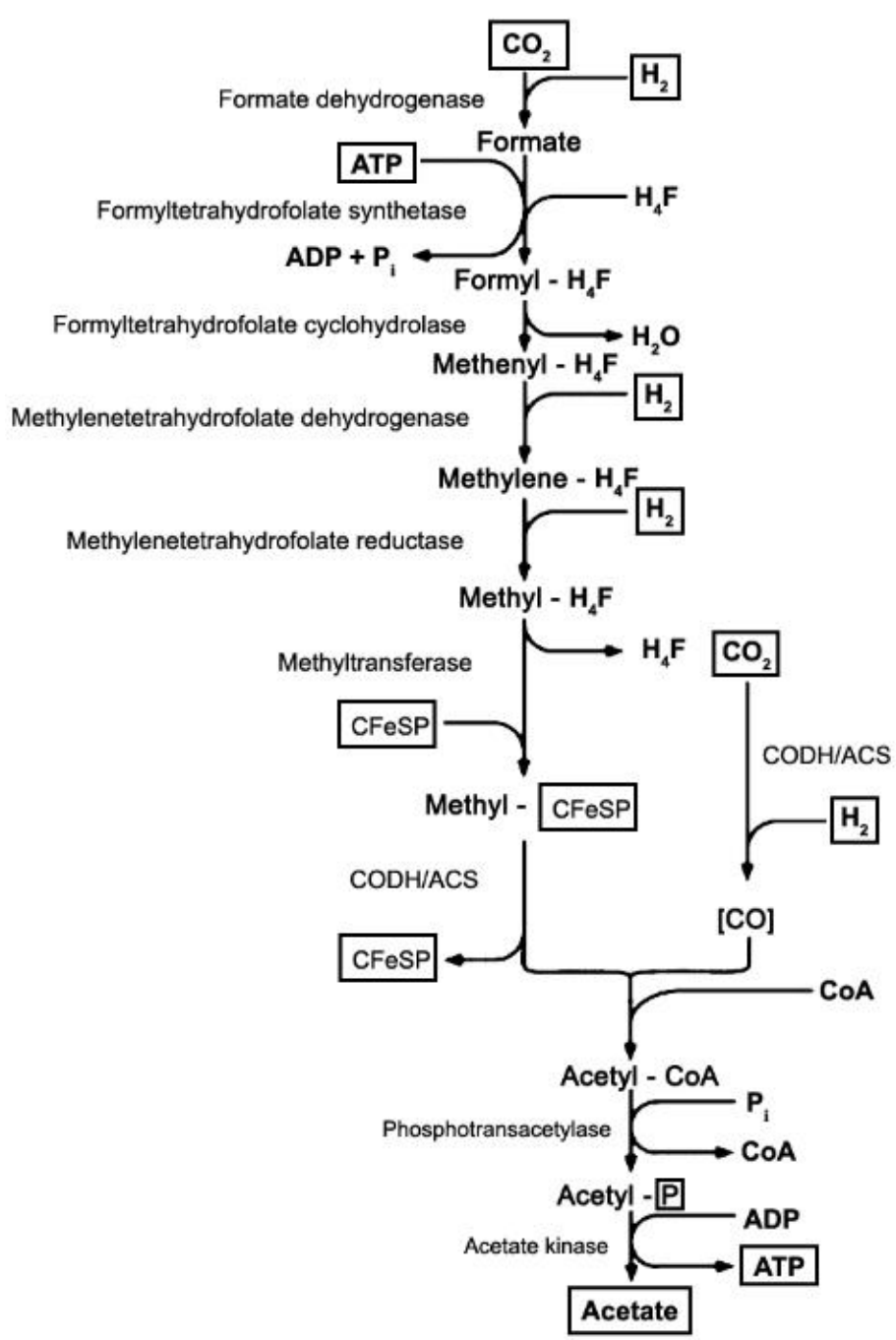

Figure 1 Production of Acetyl $\mathrm{CoA}$ and cell carbon from $\mathrm{CO}_{2}$ by WoodLjungdahl pathway (Diekert and Wohlfahrt 1994)

$$
\mathrm{C}_{6} \mathrm{H}_{12} \mathrm{O}_{6} \longrightarrow 3 \mathrm{CH}_{3} \mathrm{COO}^{-}+3 \mathrm{H}^{+}+\Delta \mathrm{G}^{0}=-310.9 \mathrm{KJ} / \mathrm{mol}
$$

The intermediate metabolic group, the obligate proton - reducing $\left(\mathrm{H}_{2}\right.$ forming $)$ acteogenic bacteria (group 2), is a complex species with the following characters: (i) oxidation of alcohols such as ethanol into acetate and hydrogen or complex the corresponding carboxylic acid, (ii) $\beta$ - oxidation of even-carbon-numbered fatty acids into acetate and odd-numbered fatty acids into acetate, propionate and $\mathrm{H} 2$, (iii) decarboxylation of propionate into acetate and $\mathrm{CO}_{2}$ or acetate and $\mathrm{H}_{2}$ (Eqn.6) and (iv) other possible reactions (Eqn.7 \& 8) (McInerney and Bryant, 1981). Long chained fatty acids are metabolized into acetate by obligate hydrogen producing acetogenic bacteria (group 2). The major products obtained after the digestion of substrate by these two groups are hydrogen, carbon dioxide and acetate (Chandrasekar, 2004).

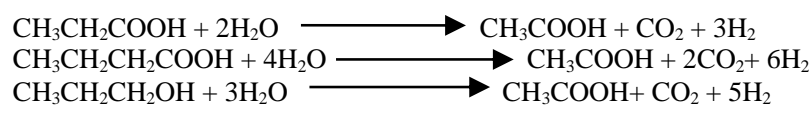

The interspecies hydrogen transfer between organism producing and consuming hydrogen promotes the decomposition of organic matter in most of the anoxic environments (Fig.2.0) (Walker et al., 2009). 


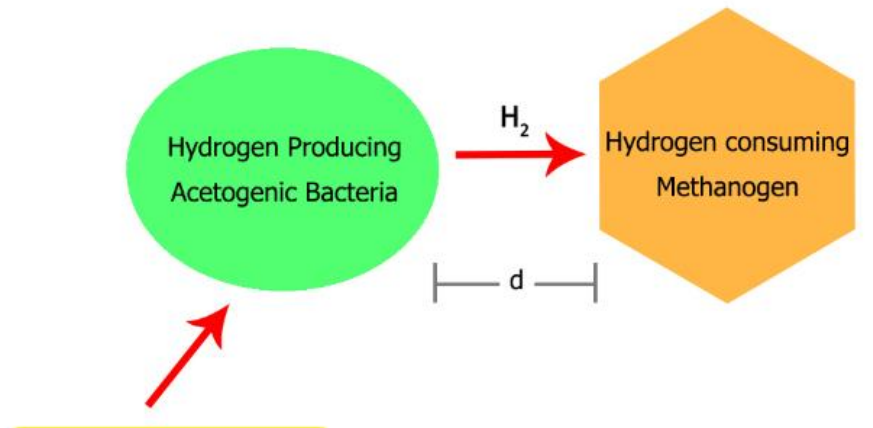

Long chain Fatty acids,

Propionate, butanol, etc.,

Where, $d$ is the critical distance between syntroph and cell

Figure 2 Interspecies hydrogen transfer between the cells (Walket et al., 2009).

The process of $\mathrm{H}_{2}$ transfer between the organisms is referred to as "Syntrophic Acetogenesis" and it is achieved by syntrophic acetogenic bacteria. The syntrophic acetogenic bacteria (in Greek; Syn: together; trophein: eat) putatively grow in a mixed culture with hydrogen consuming bacteria such as methanogens because their metabolism can be inhibited by Hydrogen. The interdependence among these partners may vary from an "Assembly line" - type of cooperation called metabiosis in which only the latter partner in the line profits from the former one but advantages to the former member in the line by the latter partners are negligible. Some examples include the degradation of glucose via acetate into methane by the cooperation of Acetobacterium woodii and Methanosarcina barkeri (Eqn.9) (Bernhad, 2006).

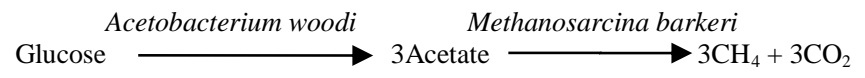

Syntrophomonas wolfei degrades straight chain fatty acids till octanoate forming acetate and propionate together with either methanogen or sulfate reducers (Schnurer et al., 1996). The inter species electron transfer between a propionate oxidizing syntroph, Pelotomaculum thermopropionicum SI, and a hydrogen consuming methanogens, Methanobacter thermoautotrophicus is facilitated by co aggregation (Ishii et al., 2005). Syntrophy model for stimulating coaggregation, the interspecies hydrogen flux between syntrophs and methanogens is estimated on Fick's diffusion law (Eqn.10).

$$
J=D_{\mathrm{H} 2} \quad \frac{C_{\mathrm{H} 2}-\text { Syntroph }}{}-C_{\mathrm{H} 2-\Delta \mathrm{H}}
$$

Where, $\quad J$ is the interspecies hydrogen flux

$D_{\mathrm{H} 2}$ is the $\mathrm{H}_{2}$ diffusion constant in water $\left(\right.$ at $\left.55^{\circ} \mathrm{C}\right)$

$C_{\mathrm{H} 2}$-Syntroph is the $\mathrm{H}_{2}$ concentration immediately outside a syntroph cell

$C_{\mathrm{H} 2}-{ }_{\mathrm{H}}$ is the $\mathrm{H}_{2}$ concentratio $\Delta$ immediately outside an ${ }_{\mathrm{H}}$ cell

$d$ is the average distance between the syntroph and the cells.

The total interspecies hydrogen flux $\left(Q_{\mathrm{H} 2}\right)$ is stoichiometrically correlated with methane mechanism rate and calculated by multiplying $J$ value by the total surface area of hydrogen-releasing syntrophic cell (Eqn.11).

$$
Q_{\mathrm{H} 2}=X_{\text {Symtroph }} \cdot V \cdot A_{S y n t r o p h} . J
$$

Where, $Q_{\mathrm{H}_{2}}$ is the total interspecies flux

$X_{\text {symtroph }}$ is the cell concentration of the syntroph

$V$ is the culture volume

$A_{\text {syntroph }}$ is surface area of a syntroph cell.

$Q_{\mathrm{H} 2}$ between the aggregated and separated cells can be separately estimated (Eqn.12-14) for partially aggregated co-cultures.

$$
\begin{aligned}
& Q_{\mathrm{H} 2 \text {-agg }}=X_{a g g-\text { symtroph }} \cdot V \cdot A_{\text {syntroph }} . J \cdot D_{\mathrm{H} 2} \frac{C_{\mathrm{H} 2-\text { syntroph }}-C_{\mathrm{H} 2}-\Delta}{-d_{a g g}} \\
& Q_{\mathrm{H} 2 \text {-dis }}=X_{\text {dis-symtroph }} . V \cdot A_{\text {Syntroph }} . J . D_{\mathrm{H} 2} C_{\mathrm{H} 2-S y n t r o p h}-C_{\mathrm{H} 2-\Delta \mathrm{H}}
\end{aligned}
$$

$Q_{\mathrm{H} 2}=Q_{\mathrm{H} 2 \text {-agg }}+Q_{\mathrm{H} 2 \text {-dis }}$

Where $Q_{\text {H2-agg }} \& Q_{\text {H2-dis }}$ are the total interspecies hydrogen flux between the aggregated and separated cells respectively, $X_{a g g \text {-symtroph }}$ and $X_{d i s-s y m t r o p h}$ are the concentration of aggregated syntroph cells and that of dispersed cells respectively, $d_{a g g}$ and $d_{d i s}$ are the mean interspecies between the aggregated and dispersed cells respectively (Ishii et al., 2005).

Walker et al. constructed an archetyphal "community of two" by pairing Desulfovibrio vulgaris with a hydrogentrophic methanogens, Methanococcus maripaldudis strain S2 in 2009. Syntrophic association between Clostridium spp., and hydrogentrophic methanogens, Methanosarcina spp. has been investigated by Karakashev et al. since 2006. Methanosarcina barkerii, growing in a syntrophic co-culture with Desulfovibrio vulgaris converts about one-third of the metabolized acetate to carbon dioxide and hydrogen (Schnurer, 1996).

The process in which $\mathrm{H}_{2}$ and $\mathrm{CO}_{2}$ convert into acetate by oxidizing acetogenic bacteria (group 3) called homoacetogenesis. Hydrogen and carbon dioxide are converted into acetate by hydrogen oxidizing acetogenic bacteria (Eqn.15\&16) (Group 3) (Chandrasekar, 2004) or may be used by the hydrogen utilizing methanogens (Eqn.17) (Gropu 4) for the production of methane or utilized by sulfur reducers and converted into $\mathrm{H}_{2} \mathrm{~S}$ (Eqn.18\&19) (Schink, 1997).

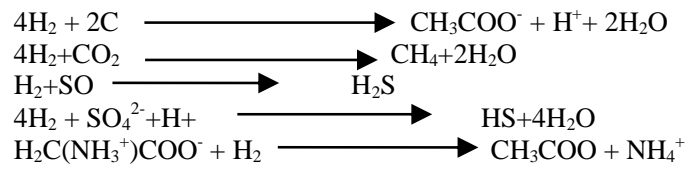

Sporomusa termitida, Desulfomicrobium hypogeum, Acetobacterium psammolithicum Ruminococcus hydrogenotrophicus $\mathrm{H}_{2}$ utilising acetogenic bacterium have been reported (Bernalier et al., 1996). Eubacterium aggregum, a homoacetogenic bacteria which was isolated from olive oil mill waste water digestor by Mechichi et al. in 1998 .

\section{Methanogenesis}

Methane production by archaea through biological process is referred to as Methanogenesis (stage 4). The biological methane production Is carried out by a special type of archaea which exhibits a prokaryotic biochemical and morphological features. Studies explored by the Carl Woese say that these organisms are phylogenetically distinct from other prokaryotes and eukaryotes. The existence of methanobacteria is now called methanoarchaea. Archaea is further classified into two main phyla of euarachaeota and crenarachaeota. Methanogens occupy the euarcahaeal branch together with non-methanogenic halophillic, thermoacidophillic and hyperthermophilic archaea. The enzyme system, suggested being an ancestral features of archaea and bacteria, which has subsequently been lost in all but a few lineages of prokaryotes (Juottonen, 2008).

In methanogenesis, about two-thirds of all methane is derived from acetate carboxylation whereas about one-third is from $\mathrm{CO}_{2}$ reduction with small amounts coming from other substrates (Zinder, 1990). The biomethanation occurs through various processes as follows; reduction of $\mathrm{CO}_{2}$ (Eqn.20) including the reduction of carbon-di-oxide into the formyl level (Eqn.21), reduction of the formyl group into formaldehyde level (Eqn.22\&23), reduction of the methylene group into methyl level (Eqn.24), conversion of the methyl group into methane via transfer of the methyl group to Co-enzyme M (Eqn.25); reductive demethylation CH3-SCoM into methane (Eqn.26 \& 27), electron transport and bioenergetics through electron carriers, hydrogenase, formate dehydrogenase, alcohol dehydrogenase; conversion of acetate into $\mathrm{CO}_{2}$ and $\mathrm{CH}_{4}$ (Eqn.28 \& 29) via the activation of acetate into acetyl Co-A, decarbonylation of acetyl Co-A, methyl trtansfer to HS$\mathrm{CoM}$, reductive demethylation of $\mathrm{CH}_{3}-\mathrm{S}-\mathrm{CoM}$ into methane, electron transport and bioenergetics and other enzyme activities; disproportionate of methanol or methylamines to methane and carbon dioxide (Eqn.30-32); methyl transfer reaction leading to methane, oxidation of the methyl group into $\mathrm{CO}_{2}$ and electron transport and bioenergetics by methanol oxidation to $\mathrm{CO}_{2}$, methanol reduction to $\mathrm{CH}_{4}$ (Ferry, 1992).

$$
\begin{array}{ll}
4 \mathrm{H}_{2}+\mathrm{CO}_{2} \longrightarrow \begin{array}{c}
\mathrm{CH}_{4}+2 \mathrm{H}_{2} \mathrm{O} \\
\Delta \mathrm{G}^{\mathrm{O}^{\prime}}=-130.4 \mathrm{~kJ} / \mathrm{mol}
\end{array} \\
\mathrm{CO}_{2}+\mathrm{MF}+\mathrm{H}_{2} \longrightarrow \begin{array}{c}
\text { Formyl-MF }+\mathrm{H}_{2} \mathrm{O} \\
\Delta \mathrm{G}^{\mathrm{O}^{\prime}}=+16 \mathrm{~kJ} / \mathrm{mol}
\end{array} \\
\text { Formyl-MF }+\mathrm{H}_{4} \mathrm{MPT} \longrightarrow \\
\Delta_{\mathrm{G}^{\mathrm{O}^{\prime}}}=-4.4 \mathrm{~kJ} / \mathrm{mol}
\end{array}
$$

5-formyl- $\mathrm{H}_{4} \mathrm{MPT}+\mathrm{H}^{+} \longrightarrow 5,10$ - methenyl-H4MPT ${ }^{+}+\mathrm{H}_{2} \mathrm{O}$

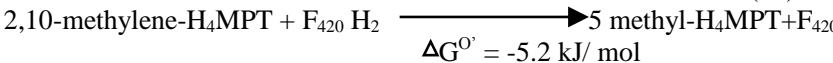




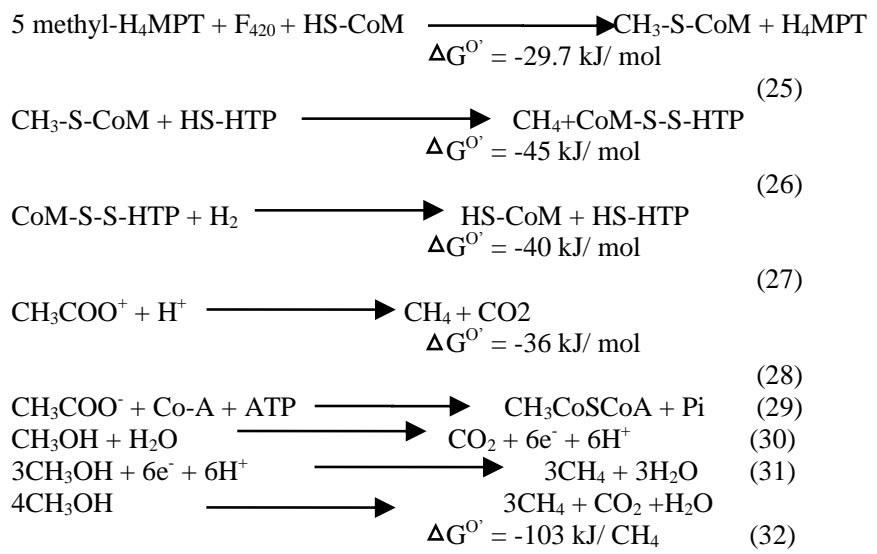

These conversions are attained by two groups of methanoarachaea such as carbon-di-oxide reducing methanogens (Group 4) and acetate utilizing methanogens or acetolastic methanogens (Group 5). The methane produced in the anaerobic reactor can be calculated using mass - calculations. Calculation for the conversion of mass based data into volumetric basis requires only a measurement or estimate the wet density (wet mass volume ${ }^{-1}$ ) (Richards et al., 1991). Biogas produced in anaerobic digestion consists of methane, carbon dioxide, water vapor and other gases in trace amounts. The calculation for the standard biogas volumes are represented in equation 33

$$
V_{O}=D B F_{t} \times V_{t}
$$

Where, $V_{O}$ is the dry (non water) biogas volume at $0^{\circ} \mathrm{C}$

$D B F_{t}$ is the dry(non-water) biogas volume at $0^{\circ} \mathrm{C}$

$V_{t}$ biogas volume measured at temperature $\mathrm{T}$.

Richards et al. (1991) has performed a temperature versus dry biogas factor regression (Eqn.34) to simplify this application. The linear regression $(\mathrm{R}=$ $0.9997)$ covers a range of common ambient temperatures $\left(15^{\circ}-27^{\circ} \mathrm{C}\right)$. The mass loss due to evaporation is calculated from the biogas volume (Eqn.35). The temperature/vapor density relationship is exponential (Eqn.36) and an exponential regression (Eqn.37) is performed. Then the corrected mass loss is represented in the equation 37. Mass removal rate $\left(M R R_{\mathrm{m}} \mathrm{g}(\mathrm{Kg} \cdot \mathrm{d})^{-1}\right)$ is defined as $M R_{\mathrm{m}}$ divided by the net reactor mass $(\mathrm{Kg})$ and length of the time interval (day).

$D B F_{t}=1-0.0045 \times \mathrm{T}$

Where, $\mathrm{T}=$ biogas temperature $\left({ }^{\circ} \mathrm{C}\right)$ within the range $15^{\circ} \mathrm{C}$ to $27^{\circ} \mathrm{C}$

$W=V_{t} \times D_{\mathrm{W}}$

Where, $W$ is the mass of water lost by evaporation in biogas (g water (biogas) $)^{-1}$ ) $V_{\mathrm{t}}$ is the biogas volume at ambient temperature

$D_{\text {w }}$ is water vapor density (g water)

$D_{\mathrm{w}}=0.005396 \mathrm{e}^{(0.05808 \mathrm{~T})}$

Where, $D_{\mathrm{w}}$ is the water vapor density

$\mathrm{T}$ is the ambient biogas temperature $\left(15^{\circ} \mathrm{C}-27^{\circ} \mathrm{C}\right)$

$M R_{m}=I-F-W$

Where, $M R_{m}$ is mass removed (or) during interval (mass loss method)

$I$ is initial reactor mass (beginning of interval)

$F$ is final reactor mass (end of interval)

$W$ is mass of water lost by evaporation in biogas.

The biogas based method of determining removals calculates the mass of dry biogas produced. The biogas mass is calculated using the molecular weight of methane and carbon-di-oxide respectively $\left(16\right.$ and $44 \mathrm{~g} \mathrm{~mol}^{-1}$,) and the molar volume of an ideal gas at STP $\left(22.41310 \mathrm{~mol}^{-1}\right)$ (Eqn.38) and by substituting $\mathrm{CO}_{2}$ $=100-\mathrm{CH} 4$ in equation 38 and simplifying the constant results (Eqn.39) and obtained the mass removal rate $M R R_{\mathrm{b}}$, $\left(\mathrm{g}(\mathrm{Kg} \cdot \mathrm{d})^{-1}\right)$ mass $(\mathrm{Kg})$ and the time interval (day). These two independent variables (Eqn.37 \& 39) yields the equal results $\left(M R R_{\mathrm{m}}=M R R_{\mathrm{b}}\right)$.

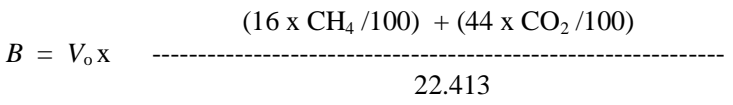

Where, $B$ is biogas mass (g)

$V_{\mathrm{o}}$ is dry biogas volume at STP

$\mathrm{CH}_{4}$ biogas normalized methane content (volume percent)
$\mathrm{CO}_{2}$ biogas normalized carbon dioxide content (volume percent)

$M R_{\mathrm{b}}=B=V_{\mathrm{o}}\left[1.963-\left(0.01249 \times \mathrm{CH}_{4}\right)\right]$

Where, $M R_{\mathrm{b}}$ is mass removed (g) (biogas method)

$V o$ is dry biogas volume STP

$\mathrm{CH}_{4}$ is biogas normalized methane content (volume percent).

Determination of hydrolytic water consumption includes both the converted substrate mass and water consumed during hydrolysis process for methane fermentation. For example, starch or cellulose with $n$ hexose units shows that $10 \%$ of the mass of biogas produced originates as water (Eqn.40). The hydrolytic factor $H$ can be determined as shown in equation 41, which assumes that the difference between the steady state volatile solids (VS) removals and mass removals is hydrolytically-consumed.

$\left(\mathrm{C}_{6} \mathrm{H}_{10} \mathrm{O}_{5}\right) n+n \mathrm{H}_{2} \mathrm{O}$

$3 n \mathrm{CO}_{2}+3 n \mathrm{CH}_{4}$

Molecular weight

$162 n$ $18 n$

Substrate mass converted $+\quad$ water mass consumed $180 n$ produced (40)

\section{$H=1-(V S R R / M R R)$}

(41)

Where, $H$ is hydrolysis factor, $\mathrm{g}$ water consumed ( $\mathrm{g}$ mass removed) ${ }^{-1}$ $V S R R$ is $V S$ removal, g VS (Kg.d $)^{-1}$

$M R R$ is mass removal rate (mass loss and/or biogas basis), $\mathrm{g}(\mathrm{Kg} . \mathrm{d})^{-1}$

The second method for the determination of $H$ is based on the fermentation stoichiometry equation (Eqn.41), in which it is assumed that ammonia released can be retained in the solution and balanced by bicarbonate derived from carbondi-oxide (Buswell equation). The coefficient generated by the equation (Eqn.41) is used to calculate the $H$ factor (Eqn.42). For example, $c$ moles of N, $x$ moles of $\mathrm{H}_{2} \mathrm{O}$ are consumed; $y$ moles of $\mathrm{CH}_{4}$ and $z$ moles of $\mathrm{CO}_{2}$ are produced (Buswell et al., 1959; Richards et al., 1991). The equation can be simplified to calculate $H$ factor (Eqn.43) by substituting the equation 42 .

$\mathrm{C} n \mathrm{H} a \mathrm{O} b \mathrm{~N} c+[n-0.25 a-0.50 b+1.75 c] \mathrm{H}_{2} \mathrm{O}[0.50 n+0.125 a-0.25 b$ $+0.375 c] \mathrm{CH}_{4+}[0.50 n-0.125 a+0.25 b-0.625 c] \mathrm{CO}_{2}+c \mathrm{NH}_{4}^{-}+c \mathrm{HCO}_{3}^{-}$

$H=(18(x-c)-c) /(16 y+44 z)$

$H=(18 n-4.5 a-9 b+12.5 c) /(30 n-3.5 a+7 b-33.5 c)$

The calculation based on Hydraulic Retention Time (CSTR) assumes the use of $Q$ as the through put, the rate of mass inflow equals the rate of mass outflow. This is technically incorrect as the mass removed as biogas is ignored. The HRT is conventionally defined as the reactor volume $(V)$ divided by the volume of liquid throughput $\left(Q\right.$, volume time $\left.{ }^{-1}\right)$. The Mass Removal Rate $(M R R)$ can be determined by the difference between the rate of inflow $(Q 0)$ and the rate of effluent outflow $(Q \mathrm{e})$. The determination of actual hydraulic retention time is represented in the equation 44

$H R T_{\text {actual }}=M / Q \mathrm{e}=M X / Q \mathrm{eX}=S R T$

here, $H R T_{\text {actual }}$ is the Hydraulic retention time

$M / Q e$ is the actual residence time of liquids in reactor (by outflow)

$M$ is the net mass loaded at rate $Q o$ (mass time ${ }^{-1}$ )

$X$ is the microbial Vs concentration in reactor and effluent.

On the contrary, the retention time based on the inflow $(M / Q \mathrm{o}$ is actualized as $H R T_{\mathrm{i}}$ ) is not the actual retention time, but it is still needed as Qo is an independent control variable. In the CSTR system Qe can be significantly less than Qe as represented in equation 45, resulting in retention times that are much longer than the $H R T_{\mathrm{i} .}$. But the ratios $\mathrm{Qo} / \mathrm{Qe}$ and SRT/HRTi are found to be increasing with the extent of substrate conversion. $S R T / H R T_{\mathrm{i}}$ ratios approximately to 2 are possible in high solids reactor fed with highly biodegradable substrate.

$S R T=M / Q \mathrm{e}>M / Q \mathrm{o}=H R T_{\mathrm{i}}$

The first order CSTR kinetic reaction (Eqn.46) is modified by Richards et al. (1991) on the mass basis, accounts for biogas mass losses with distinguishing $Q 0$ and $Q$ e (Eqn.47).

Change Substrate Mass = Influent Substrate Mass - Effluent Substrate Mass Substrate Mass Removed in Biogas

$M \mathrm{dS} / \mathrm{d} t=Q \mathrm{oSO}-Q \mathrm{eSe}-k M S \mathrm{e}$

Where, $M$ is reactor wet mass 
$\mathrm{d} S / \mathrm{d} t$ is rate of change of substrate concentration, mass mass ${ }^{-1}$

$Q$ o is rate of inflow, wet mass time ${ }^{-1}$

$Q$ e is rate of outflow, wet mass time ${ }^{-1}$

So is influent substrate concentration, substrate mass (wet mass ${ }^{-1}$ )

$K$ is first order rate coefficient, time

By definition, $\mathrm{d} S / \mathrm{t}$ at steady state equals to zero (Eqn.48), thus

$Q \mathrm{o} S \mathrm{o}-Q \mathrm{e} S \mathrm{e}-k M S \mathrm{e}=0$

A constant reactor mass requires that inflow equal outflow plus biogas mass removals (the removal rate $(k M S e)$ divided by the $(1-\mathrm{H})$ terms yields the mass removal rate) (Eqn.49).

$Q \mathrm{o}=Q \mathrm{e}+k M S \mathrm{e} /(1-H)$

Where, $H$ is substrate hydrolysis factor, more water consumed (mass loss) ${ }^{-1}$

Substituting the relationship for $Q$ o and the definition of $S R T(M / Q \mathrm{e})$ in equation 48 and solving $\mathrm{k}$ are shown in equation $50 \& 51$ on the basis of $H R T_{\mathrm{i}}$. Substrate concentrations So and $S$ e are easily calculated from biodegradable VS (BVS) loading and removal rates (Eqn.52\&53) (Richards et al., 1991).

$K=(S \mathrm{O}-\mathrm{Se}) /\left[S \mathrm{Se} H R T_{\mathrm{i}}(1-\mathrm{So} /(1-H)]\right.$

$K=(S \mathrm{O}-\mathrm{Se}) /\left[\mathrm{Se} H R T_{\mathrm{i}}(1-\mathrm{Se} /(1-H)]\right.$

So $=B L R /\left(1000 / H R T_{\mathrm{i}}\right)$

$\mathrm{Se}=(B L R-R R) /\left[\left(1000 / H R T_{\mathrm{i}}\right)-M R R\right]$

Where, $B L R$ is $B V S$ loading rate, $\mathrm{g} B V S(\mathrm{Kg} . \mathrm{d})^{-1}$

$R R$ is $V S$ removal rate, $\mathrm{g} V S(\mathrm{Kg} . \mathrm{d})^{-1}$

$M R R$ is mass removal rate, $\mathrm{g}(\mathrm{Kg} . \mathrm{d})^{-1}$

The relationship between the biogas production and the substrate utilization can be estimated by this kinetics reaction.

\section{Sulfate Reduction in Anaerobic Digestion}

The sulfate reducing bacteria are normally dominant in various natural habitats such as fresh and marine sediments and also in anaerobic digester. In anaerobic digestion, the hydrolysed products such as monosaccharide, amino acids, higher fatty acids and alcohols and the intermediate products like acetate, $\mathrm{H}_{2}$ and $\mathrm{CO}_{2}$ (Eqn.54-59) with the presence of sulfate and sulfite are used by the sulfate reducers, which use these compounds as electron acceptor during the oxidation of organic materials under anaerobic conditions. This condition creates a critical competition in substrate utilization used in sulfite reduction instead of fermentation. If Acetogenesis and Methanogenesis are reduced, this apparently reduces methane formation. By these, the sulfate reducing bacteria can utilize 53$93 \%$ of the available substrate electrons in anaerobic digestion as reported by Zaid et al. 1986.

$$
\begin{aligned}
& 4 \mathrm{H}_{2}+\mathrm{SO}_{4}{ }^{2-}+\mathrm{H}^{+} \underset{\Delta \mathrm{G}^{\mathrm{O}^{\prime}}=-151.9 \mathrm{~kJ} / \mathrm{mol}}{\mathrm{HS}^{-}+4 \mathrm{H}_{2} \mathrm{O}} \\
& \text { Acetate }+\mathrm{SO}_{4}{ }^{2-} \longrightarrow 2 \mathrm{HCO}_{3}{ }^{-}+\mathrm{HS} \\
& \text { Propionate }+3 / 4 \mathrm{SO}_{4}{ }^{2-} \longrightarrow \text { Acetate- }+\mathrm{HCO}_{3}{ }^{-}+3 / 4 \mathrm{HS} \\
& \Delta \mathrm{G}^{\mathrm{O}^{\prime}}=-37.7 \mathrm{~kJ} / \mathrm{mol}
\end{aligned}
$$

Substrate for Anaerobic Digestion

The successful anaerobic digestion process can be achieved using suitable substrate by utilizing various organic materials to produce energy.

\section{Municipal Solid Waste and Industrial wastes}

The solid wastes are produced by day to day human activity and abounded by the people. These domestic wastes mainly consist of biodegradable waste including food waste, the remainings vegetable and fruits, green waste, cellulosic materials like papers, carton etc.
The wastes produced by household, market, hotel, sewage waste and sludge, human excretory waste can act as a good source for anaerobic digestion. Various types of municipal solid waste are exploited by various researchers for successful digestion process that encompasses food market waste, utilization of fruit and vegetable waste, canteen wastes, market waste, food waste (Forster et al., 2008) Rao and Singh (2003) used various wastes such as food wastes from fruits and vegetable markets, household wastes and wastes from hotels and juice centers (Dawei et al., 2006).

Deploying of domestic kitchen wastes is useful for biomethanation process (Chandrasekar, 2004) and with black water (Elimitwalli et al., 2006) Consumption of olive oil mill wastes include house hold wastes, sewage slaughter house waste water and sewage water, organic fraction of municipal solid waste, waste activated sludge and sewage sludge (Forster et al., 2008; Yebo Li et al., 2011). Yen and Brune (2007) employed algal sludge and paper waste for biogas production.

\section{Agricultural Waste}

The agricultural wastes starting from agricultural bi-products to farmyard dung can act as a good basis of feedstock for anaerobic digestion process. They include waste from livestock, cow slurry, pig slurry, chicken slurry, farmyard manure, harvest remains and garden wastes, energy crops, feedlot runoff, silage juices, waste and waste water from agricultural related process (Wilson, 2004). The cattle dung not only acts as a good source of feedstock but also found to be the basis of inoculum for anaerobic digestion for the production of methane and other bi-products. The farmyard materials, agricultural residues and cattle litters possess rich source of carbohydrates proteins and other growth nutrients required for digestion process. Holm-Nielsen et al. 2009 employed animal manure, anima waste and slurries for anaerobic process. Deploying of piggery wastes, agricultural wastes, lignocellulosic biomass, energy crops like aquatic and marine plants and grasses and woods is helpful for the production of methane gas via anaerobic digestion (Alastair et al., 2008).

Prochnow et al. 2009 employed different variety of grass species for biogas production via anaerobic digestion. Leaf residues of Gulmohar, Leucacena leucocephala, Acacia auriculiformis, Dalbergia sisoo and Eucalyptus tereticonius and plant residues like Lantan, wheat straw, apple leaf litter and peach leaf litter supplemented with cattle dung are used for biogas production process (Yadavika et al., 2004). Deploying palm oil mill waste with co-digestion of cattle manure accompanied with agro wastes and energy crops is used for the fermentation process (Cairnats et al., 2010). Grass silage and animal manure, lignocellulosic crop residues are used in co-digestion process for the production of methane (Yebo Li et al., 2011). Therefore any combination of solid waste can be incorporated for successful anaerobic fermentation depending upon its regional availability

Effect of Various Parameters in Anaerobic Digestion and Methane Production

\section{Substrate Enhancement by Pretreatment and Co - Digestion}

Naturally hemicellulosic and lignocellulosic materials resist biological degradation highly as the anaerobic digestion process is highly operated with substrate rich in cellulosic materials (Taherzadeh and Karimi 2008). The digestion process initiated by hydrolysis continues to methanogenesis and ends with methane as the end product. The efficient methane production is highly dependent on hydrolytic process. In order to obtain the effective hydrolysis process, the lignocellulosic compounds are subjected to different pretreatment methods (Venkata et al., 2008). The pretreatment process can be achieved by various methods including physical, chemical, physhicochemical and biological methods for the better production of ethanol and biogas. Physical pretreatment methods like milling, ultrasonificaton, microwave treatment, irradiation, thermal treatment and other pressurized methods are adopted by various researchers (Elliott and Mahmood 2007; Yu et al., 2010).

Chemical and physicochemical method comprises ammonia explosion method thermal explosion method, thermo-chemical methods, alkali treatment, acid treatment, gas treatment, treating with ozone, treating with oxidizing agent and other solvent extraction methods for methane and ethanol production (Elliott and Mahmood 2007; Xialing et al., 2008). Biological pretreatment encloses treatment with the fungus and actinomycetes for depolymerization and partial hydrolysis of hemicelluloses (Venkata et al., 2008).

Secondly, lipids and proteins represent an important fraction of the particular organic materials. In the anaerobic treatment process, the methane production is slowed down or impaired by high suspended solids particularly by lipids and fats (Saxena et al., 1986). In anaerobic digestion process, pretreatment of fat is achieved by enzymatic methods, alkaline hydrolysis method and by other methods (Masse et al., 2003). The anaerobic digestion can be further enhanced by co-digestion process. The co-digestion process is the combination of one or more typical substrate utilized for the operation of anaerobic digestion and various co-digestion processes are successfully adopted (Maritza et al., 2008). 


\section{Effect of Ammonia}

Various substrates are utilized for the anaerobic digester, which contains carbohydrates, proteins, lipids and other nutrient required for the development for microbial consortium for methane production. When the protein and urea rich substrates are hydrolysed, it results in the generation of free ammonia from the substrate (Kayhanian, 1999). The free ammonia has been suggested to be inhibiting digestion process since its membrane is permeable. The amount of ammonia produced during the degradation of biological compounds in an anaerobic digestion is estimated by the following stoichiometric equation (Eqn.61) (Tchobanoglous et al., 1993).

$$
\begin{aligned}
& \mathrm{C} a \mathrm{H} b \mathrm{Oc} \mathrm{Nd}+\frac{4 \mathrm{a}-\mathrm{b}-2 \mathrm{c}-3 \mathrm{~d}}{4} \mathrm{H} 2 \mathrm{O}>\frac{4 \mathrm{a}+\mathrm{b}-2 \mathrm{c}-3 \mathrm{~d}}{8} \mathrm{CH} 4+\frac{4 \mathrm{a}-\mathrm{b}+2 \mathrm{c}+3 \mathrm{~d}}{8} \\
& +d \mathrm{NH}_{3}
\end{aligned}
$$

Nitrogen is an essential nutrient for the growth and development of microorganism, which are available in the form of $\mathrm{NH}_{3}$. Ammonia can inhibit the cellular metabolism by various mechanisms like altering the intracellular $\mathrm{pH}$ increasing the energy requirement for cellular maintenance, blocking or inhibiting the specific enzymatic reactions (Elliott and Mahmood., 2007). These free ammonia are hydrophobic, membrane permeable in nature, easily diffuse passively into the cells causing proton imbalance and potassium deficiency. When its concentration is below $200 \mathrm{mg} . \mathrm{L}^{-1}$, it supports the growth of anaerobic microorganisms. The concentration of ammonia increases in the range of 4051 $5374 \mathrm{mg} . \mathrm{L}^{-1}$ and hardly affects acidogenic population and methanogenic activity up to $56.5 \%$ (Liu and Sung, 2002). In order to overcome this, ammonia present in the substrate is removed by physical and chemical method. Both air stripping and chemical precipitation method in waste water matrix have been proven to be technically feasible (Kabdasli et al., 2000). The microorganisms immobilized on various inert materials like activated carbon, clay and zeolites have been established to increase methane production and make the process more stable. Various ion changers and adsorbants made up of natural zeolite and glauconite were used to reduce ammonia inhibition in digestor process (Borja et al., 1996 and Hansen et al., 1998).

\section{EFFECT OF LIPIDS, VFA'S AND pH}

The lipids and fats are added to the reactor system in order to enhance the production of methane (Ahring, 2003). The reactor system is operated by lipid rich wastes obtained from various point sources such as slaughter house, food processing industries, dairy industries, edible oil processing industries, olive oil processing industries, fish processing industries etc. The lipids and fats directly affect the reactor operation by clogging and floating of biomass due to the adhesion of fat during the operation conditions and it will lead to low efficiency of the system (Pereira et al., 2004). In the digestion process the lipids are primarily hydrolysed into glycerol and they free fatty acids. Further, glycerol is converted into acetate by acidogenesis and long chain fatty acids. The long chain fatty acids are converted into acetate or propionate or hydrogen through $\beta$ oxidation pathway (syntrophic acetogenesis). The LCFAs are suggested to be the actual toxic agents, which in case of affecting the growth and activity of the acetolastic and hydrogenotrophic methanogens leads to permanent failure of the system. The increased VFAs and $\mathrm{pH}$ in the digestion process leads to "reactor upset" and reduces methane yield (Veeken and Hamelers., 2000). However, anaerobic reactor can be successfully operated at wide $\mathrm{pH}$ range depending on the methanogenic diversity. The total ammonia and nitrogen, $\mathrm{pH}$ and volatile fatty acid adversely modulate the microbial growth and methane yield (Hansen $e$ al., 1999). The pH fluctuations in the reactors occur due to various condition like free ammonia concentration, VFAs productions, substrate characteristics. But the major cause for $\mathrm{pH}$ alterations is due to the accumulation of free ammonia and it has been suggested to be the actual toxic substance (Borja et al., 1996). The accumulation of free ammonia in digester system leads to the increased production of VFAs. In case it again reduces the $\mathrm{pH}$ of the system, instability will occur in the process (Angelidaki and Ahring, 1992). But various studies show that the reactors operate at various $\mathrm{pH}$ ranges depending upon the product consideration and substrate characterization (Yuan et al., 2006). The methanogenic archaea mostly prefers neutral $\mathrm{pH}$ to the metabolism of acetate, $\mathrm{H}_{2}$ and $\mathrm{CO}_{2}$ (Taconi et al., 2008). The optimum $\mathrm{pH}$ range relies between6.5-8.5 and the methanogenesis process is completely inhibited $\mathrm{pH}$ below 5.0 for the enhanced methane production (Kim et al., 2003). In order to overcome this, proper pretreatment process should be adopted depending upon the strength and type of the substrate used. Further, the substrate type and its particulate concentration confined microbial consortium should be selected to obtain the enhanced methane yield.
Anaerobic digestion is operated at several temperature ranges for methane production process including thermophilic $\left(45^{\circ} \mathrm{C}\right.$ and above), mesophilic (25$\left.45^{\circ} \mathrm{C}\right)$, psychrophilic $\left(10-15^{\circ} \mathrm{C}\right)$ have been reported by Stanier and Niel, 1962. But, mostly the anaerobic digestion process is carried out at mesophilic to thermophilic conditions. Nowadays it is possible to operate digestion process under psychrophilic condition for methane production (Katarzyna et al., 2013) However, the operational condition of digestion process under different temperature has its own advantages and disadvantages. The mesophilic digestion process is more stable and easy to control thermophilic conditions. When thermophilic process is compared with mesophilic process, the rate of digestion will be greater than that of one-third of mesophilic process which results in high yield of methane (Chandrasekar et al., 2004). The Psychrophilic Anaerobic Digestion Process (PADP) or Low Temperature Digestion Process (LTDP) can reduce the operational cost. Further, it can improve the energy balance of the plant (McKeown et al., 2012). But more or less thermophilic process is found to be more successful in practical because it not only increases the methane yield but also lowers the retention time, improves dewaterability of the sludge, increases the destruction of pathogens and increases hydrogen yield which are further utilized by hydrogenotrophic methanogens for the enhanced methane production (Vindis et al., 2009). Various operational temperatures, which indicates that organic loading rate and microbial diversity particularly methanogenic consortium plays a vital role for methane formation. In the northern part of India, it is recorded that a short fall in biogas output during the winter and in some part of country the digestor performance has also affected higher temperature (Ramasamy, 1997). But the diurnal temperature does not have any negative impact on the digestion process. The above mentioned conditions and the fluxes in methane production are mainly due to the inadaptability of microbial diversity present in the digestor which is operated in continuous culture system.

\section{EFFECT OF METAL IONS}

It is a biological process in which metal ions are produced from organic load used in the digestion process itself. It consists of light metal ions and heavy metal ion (sewage, sludge and other waste water) or it contains additional $\mathrm{pH}$ adjustment chemicals depending upon the varieties of substrate (Graddy et al., 1999). Most of the light metal ions are required for microbial growth which includes sodium $(\mathrm{Na})$, Potasium (K), Magnesium (Mg), Calcium (Ca) and Aluminium (Al) at specific rate. If the salt concentration increases, it will lead to the osmotic imbalance which slows down the microbial growth but it will result in the death of cell in the excess rate (Soto et al., 1993). The heavy metals are present in the sewage, waste water and sludge etc. at a significance concentration depending upon their process of production. The heavy metal ions like Chromium (Cr), Iron $(\mathrm{Fe})$, Cobalt $(\mathrm{Co})$, Copper $(\mathrm{Cu})$, Zinc $(\mathrm{Zn})$, Cadmium $(\mathrm{Cd})$ and Nickel were reported by Jin et al. 1998. Not like other compounds these are non biodegradable and accumulate in digestor which leads to process imbalance by toxic effects (Steritt and Lester, 1980). Numerous anaerobic reactions take place in the presence of heavy metal ions as a part of their essential enzymes. Heavy metal concentration present in ten methanogenic isolates are found in the following order: $\mathrm{Fe}>>\mathrm{Zn}>/ \mathrm{Ni}>\mathrm{Co}=\mathrm{Mo}>\mathrm{Cu}$ (Takashima and Speece, 1989). The increased heavy metal ion concentration in anaerobic digestion process causes change in enzyme function, alters structure by binding with thiol, binding to protein molecules and it replaces natural occurring metal ions present in the prosthetic group (Vallee and Vulner, 1972). The stimulatory and inhibitory effects of these metal ions mainly depend on the chemical forms of the metal process related by $\mathrm{pH}$ or Redox potentials and the total metal ion concentrations (Zayed and Winter 2000). These metal ions not only inhibit the process by individual concentration but also play a synergistic and/or antagonistic effect by the concentration of two or more metal ions. The light metal ion combination of potassium $\mathrm{K}$ and $\mathrm{Ca}$ significantly increase the antagonistic nature that of $\mathrm{K}$ alone (Kugelman and McCarty, 1964). The antagonistic and or synergistic effects of the mixed heavy metal ions such as $\mathrm{Cr}-\mathrm{Cd}, \mathrm{Cr}-\mathrm{Pb}, \mathrm{Cr}-\mathrm{Cd}-\mathrm{Pb}$ and $\mathrm{Zn}-\mathrm{Ca}-\mathrm{Ni}$ are reported by Lin, 1992

\section{CONCLUSION}

Anaerobic digestion process occurs naturally and it is a key point for solid waste and waste water management. The byproduct produced at the end of digestion process includes methane, hydrogen, and digestate (Fertilizers) with potentia commercial value. This process is also environmental friendly (Eco-Neutral) and will be an effective remedy for carbon-di-oxide sequestration. However, the process is operated under various parameters which directly or indirectly depend on the growth of microbial consortium. Starting from acidogenesis (stage1) to methanogenesis (stage4), the process is interdependent with each other. If anyone of the stage fails to function, it will automatically reduce the efficiency of the digestion process. The efficiency of the digestion process mainly depends upon the type of substrate, microbial consortium, and operational conditions. Obtaining the information on anaerobic digestion process is necessary for the successful implementation of the process. So, it is suggested that every small things should 
necessarily be considered for the sophistication of microbial consortium for enhanced digestion process.

\section{REFERENCES}

Ahring, B. K. (2003) Perspectives in anaerobic digestion. In: Ahring. B.K., editor. Biomethnation I. Advances in biochemical engineering/Biotechnology( p1-30). Vol. 81. Berlin: Springer. http://dx.doi.org/10.1007/3-540-45839-5 1

Alastair, J. W., Hobbs, P. J., Holliman, P. J. \& Jones, O. T. (2008). Optimization of the anaerobic digestion of agricultural resources. Bioresources Technology; 99:7928-7940. http://dx.doi.org/10.1016/j.biortech.2008.02.044

Angelidaki, I. \& Ahring, B. K. (1992). Effects of free long-chain fatty acids on thermophilic anaerobic digestion. Applied Microbiology and Biotechnology; 37:808-12. http://dx.doi.org/10.1007/bf00174850

Angelidaki, I., Karakashev, D., Batstone, D. J., Plugger, C. M. \& Strams, A. J. M. (2011). Biomethanation and its potential. Methods in Enzymology; 494(16):327-351. http://dx.doi.org/10.1016/b978-0-12-385112-3.00016-0

Archer, D. B. 1983. The microbial basis of process control in methanogenic fermentation of soluble wastes. Enzyme and Microbial Technology, 5, pp.162169. http://dx.doi.org/10.1016/0141-0229(83)90089-3

Bernailer, A., Willems, A., Leclere, M., Rochet, V. \& Collins, M. D. (1996) Ruminococcus hydrogenotrophicus sp. nov., a new $\mathrm{H} 2 / \mathrm{CO} 2-$ utilizing acetogenic bacterium isolates from human faeces. Archives of Microbiology; 166(3):176183. http://dx.doi.org/10.1007/s002030050373

Bernhad, S. (2006). Syntrophic associations in methanogenic degradation Molecular basis of Symbiosis/Jorg Overman (ed.)(p1-19). Berlin Springer. http://dx.doi.org/10.1007/3-540-28221-1 1

Bolzonella, D., Fatone, F., Pavan, P. \& Cecchi, F. (2005). Anaerobic fermentation of organic municipal wastes for the production of soluble organic compounds. Industrial Engineering Chemistry Research.; 44:3412-3418. http://dx.doi.org/10.1021/ie048937m

Borja, R., Sanchez, E., \& Weiland, P. (1996). Influence of ammonia concentration on thermophilic anaerobic digestion of cattle manure in upflow anaerobic sludge blanket (USAB) reactors. Process Biochemistry; 31(5):477-83 http://dx.doi.org/10.1016/0032-9592(95)00099-2

Bryant, M.P. (1979). Microbial methane production theoretical aspects. Journal and Animal Science; 48:193-201.

Buswell, A. M., \& Mueller, H. F. (1995). Mechanism of methane fermentation. Industrial and Engineering Chemistry; 44:550 552. http://dx.doi.org/10.1021/ie50507a033

Cammarota, M. C. \& Friere, D. M. G. (2006). An review on hydrolytic enzymes in the treatment of waste water with high oil and grease content. Bioresource Technology; 97:2195-2210. http://dx.doi.org/10.1016/j.biortech.2006.02.030 Chandrasekar, V. (2004). Biomethnation kinetics of kitchen refuse and characterization of methanogenic consortia. A Dissertation submitted to fulfillment of Doctor of Philosophy to Bharathiar University, India.

Dawei Liu., Dapeng Liu., Raymond, J. Z. \& Angelidaki, I. (2006). Hydrogen and methane production from household solid waste in the two stage fermentation $\begin{array}{llll}\text { process. } & \text { Water } & \text { Research; } & 40(11) \text { : }\end{array}$ http://dx.doi.org/10.1016/j.watres.2006.03.029

Diekert, G., \& Wohlfahrt, G. (1994). Metabolism of homoacetogens. Antonie Leeuwenhoek; 66:209-221. http://dx.doi.org/10.1007/bf00871640

Elliott, A \& Mahmood, T. (2007). Pretreatment technologies for advancing anaerobic digestion of pulp and paper biotreatment residues. Water Research 41(19):4273-4786. http://dx.doi.org/10.1016/j.watres.2007.06.017

Elmitwalli, T. A., Leeuwen, V. A., Kujawa-Roeleveld, K., Sanders, W. \& Zeeman, G. (2006). Anaerobic biodegradability and digestion in accumulation system for concentrated black water and kitchen organic waste. Water Science and Technology; 53(8): 167-175. http://dx.doi.org/10.2166/wst.2006.247

Elsden, S. R., Hilton, M. C. \& Waller, J. M. (1976). The end products of the metabolism of aromatic acids by Clostridia. Archives of Microbiology; 107(3):283-288. http://dx.doi.org/10.1007/bf00425340

Ferry, J .G. (1992). Biochemistry of methanogenesis. Critical Reviews in Biochemistry and Molecular biology; 27(6):473-503. http://dx.doi.org/10.3109/10409239209082570

Ferry, J. G. \& Lessener, D. J. (2008). Methanogenesis in marine sediments. Annals of New York Academy of Sciences; 1125: 147-157. http://dx.doi.org/10.1196/annals.1419.007

Graddy Jr, C. P. L., Daigger, G. T. \& Lim, H. C. (1999). Biological Waste water Treatment. 2nd Edition, Marcel Dekker, New York.

Hansen, K. K., Angelidaki, I. \& Ahring, B. K.. (1998). Anaerobic digestion of swine manure: inhibition by ammonia. Water Research; 32:5-12. http://dx.doi.org/10.1016/s0043-1354(97)00201-7

Holm-Nielsen, J. B., Al-Seadi, T. \& Oleskowicz-Popiel, P. (2009). The future of anaerobic and biogas utilization. Bioresource Technology; 100:5478-5484 http://dx.doi.org/10.1016/j.biortech.2008.12.046

Ishii, S., Kosaka, T., Hori, K., Hotta, Y. \& Watanabe, K. (2005). Coaggregation facilities and interspecies hydrogen transfer between Pelotomaculum thermopropionicum and Methanothermobacter thermoautotrophicus. Applied and Environmental Microbiology;

$71: 7838$

7845. http://dx.doi.org/10.1128/aem.71.12.7838-7845.2005

Jin, P., Bhattacharya, S. K., Williama, C. J. \& Zhang, H. (1998). Effects of sulfide addition on copper inhibition in methanogenic system. Water Research 32:977-988. http://dx.doi.org/10.1016/s0043-1354(97)00300-x

Juottonen, H. (2008). Archaea, bacteria, \& methane production along the environmental gradients in fens and fogs. Academic dissertation in general microbiology. Faculty of Biosciences. University of Helsinki, Helsinki, Finland. http://dx.doi.org/10.1017/s0376892900003635

Kabdasli, I., Tunay, O., Oztruk, I., Yilmaz, S. \& Arikan, O. (2000). Ammonia removal from young landfill leachate by magnesium ammonium phosphate precipitation and air stripping. Water Science and Technology; 41:237-40.

Kalyuzhnyi, S., Veeken, A. \& Hamders, B. (2000). Two- particle model of anaerobic solid state fermentation. Water Science and Technology. 1:332-339.

Karakashev, D., Batstone, B. J., Trably, E. \& Angelidaki, I. (2006). Acetate oxidation is the dominan methanogenic pathway from acetate in the absence of Methanosaetaceae. Applied and Environmental Microbiology; 75:5138-5141. http://dx.doi.org/10.1128/aem.00489-06

Katarzyna, B., Denise, C. \& O'Flaherty, V. (2013). Low-temperature $\left(10^{\circ} \mathrm{C}\right)$ anaerobic digestion of dilute diary wastewater in an EGSB bioreactor: microbial community, structure, populations dynamics and kinetics of methanogenic population. Archaea; 2013:1-10. http://dx.doi.org/10.1155/2013/346171

Kayhanian, M. (1999). Ammonia inhibition in high solids biogasification: an overview and practical solutions. Environmental Technology; 20:355-65 http://dx.doi.org/10.1155/2013/346171

Kim, J., Park. C., Kim, T. H., Lee, M., Kim, S., Kim, S. W. \& Lee, J. (2003) Effects of various pretreatments for enhanced anaerobic digestion with waste activate sludge. Journal of Bioscience and Bioengineering; 95:271-275. http://dx.doi.org/10.1016/s1389-1723(03)80028-2

Kugelman, I. J. \& McCarty, P. L. (1964). Cation toxicity and stimulation in anaerobic waste treatment. Journal of water Pollution and Control Federation; 37:97-116.

Leschine, S. D. (1995). Cellulose degradation in anaerobic environment. Annual review $\quad$ of $\quad$ Microbiology; $49: 399-426$ http://dx.doi.org/10.1146/annurev.micro.49.1.399

Lin, C. Y. (1992). Effect of heavy metals on volatile fatty acid degradation in anaerobic digestion. Water Research; 26:177-183 http://dx.doi.org/10.1016/0043-1354(92)90217-r

Liu, T., \& Sung, S. (2002). Ammonia inhibition on thermophilic acetolastic methanogens. Water Science and Technology; 45:113-20. http://dx.doi.org/10.1016/s0045-6535(03)00434-x

Mackie, R. I., White, B. A. \& Bryant, M. P. (1991). Lipid metabolism in anaerobic ecosystem. A Critical Review in Microbiology; 17:449479. http://dx.doi.org/10.3109/10408419109115208

Man, D. K., Minkung, S., Minho, J., Seung, G. S., Jee, H. K. \& Seokhwan, H. (2010). Growth conditions and bacterial community for maximum hydrolysis of suspended organic materials in anaerobic digestion of food waste recycling water. Applied Microbiology and Biotechnology; 85(5):1611 1618. http://dx.doi.org/10.1007/s00253-009-2316-X

Maritza, M. C., Zohrab, S., Hanson, A., Smith, G., Funk, P., Yu, H. \& Longworth, J. (2008). Anaerobic digestion of municipal solid waste and agricultural waste and the effect of co-digestion with dairy cow manure. Bioresource Technology; 99:8288-8293. http://dx.doi.org/10.1016/j.biortech.2008.03.057

Mark, A. L. (2012). Acetogenesis in the energy-starved deep biosphere - a paradox? Frontiers in Microbiology; 2(284):1-18 http://dx.doi.org/10.3389/fmicb.2011.00284

Masse'L., Masse'D. I., \& Kennedy, K. J. (2003). Effect of hydrolysis fat degradation during anaerobic digestion of slaughter house waste water. Process Biochemistry; 38: 1365-1372. http://dx.doi.org/10.1016/s0032-9592(03)00020-7 McInerney, M. J. \& Bryant, M. P. (1981). Anaerobic degradation of lactate by syntrophic association of Methanosarcina barkeri and Desulfovibrio species and effect of $\mathrm{H}_{2}$ on acetate degradation. Applied and Environmental Microbiology; 41(2): 346-354.

Mckewon, R. M., Hughes, D., Collins, G., Mahony, T. \& O’Flaherty, V. (2012) Low temperature of anaerobic digestion of waste water treatment. Current Opnion in Biotechnology;

23(3):444-451.

http://dx.doi.org/10.1016/j.copbio.2011.11.025

Mechichi, T., Labat, M., Swoo. T. H., Thomas, P., Gracia, J-L. \& Patel, B. K. C (1998). Eubacterium aggregans sp. nov., a new homoacetogenic bacterium from olive mill waste water treatment digester. Anaerobe; 4(6):283-291. http://dx.doi.org/10.1006/anae.1998.0179

Municipal and agricultural solid waste solutions. http://www.americanbiogascouncil.org, Department for Environment and Rura Affairs, 2011

Nagarwala Nazifa. N. (1987). Studies on thermophilic anaerobic cellulolytic bacteria. Ph.D. Thesis. University of Poona, Pune. India.

Pereira, M. A., Sousa, D. Z., Mota, M. \& Alves, M. M. (2004). Minerlization of LCFA associated to anaerobic sludge: kinetics, transport, limitations, 
enhancement of methanogenic activity and effect of VFA. Biotechnology and Bioengineering; 88(4):502-10. http://dx.doi.org/10.1002/bit.20278

Prochnow, A.,Heiermann, M., Plochl, M., Linke, B., Idler, C., Amon, T. \& Hobbs, P. J. (2009). Bioenergy from permanent grassland - A review: Biogas. Bioresource Technology:100: 4931-4944. http://dx.doi.org/10.1016/j.biortech.2009.05.070

Ragsdale, W. S. \& Pierce, E. (2008). Acetogenesis and the Wood-Ljungdhal pathyway of CO2 fixation. Biochimica et Biophysics Acta; 1784:1873-1898. http://dx.doi.org/10.1016/j.bbapap.2008.08.012

Ramasamy, K. (1997). Proceeding National Symbosium on Community and institutional biogas complexes, held at Punjab agricultural University, Ludhiana. 4-5.

Ramsay, I. R. \& Pullammanapallil. P. (2001). Protein degradation during anaerobic waste water treatment. Biodegradation. 12:247257. http://dx.doi.org/10.1023/a:1013116728817

Richards, B. K., Cumming, R. J., White, T. E., \& Jewell, J. W. (1991). Methods for kinetic analysis of methane fermentation in high solids biogas digesters Biomass and Bioenergy; 2:65-73. http://dx.doi.org/10.1016/09619534(91)90028-b

Saxena, K.L., S.N. Kaul, M.Z. Hasan, S.K. Gadkari and S.D. Badrinath. (1986) Packed bed anaerobic reactor for treatment of meat wastes. Asian Environment 8:20-24. http://dx.doi.org/10.1016/0269-7483(90)90045-t

Schink, B. (1997). Energectics in syntrophic cooperation in methanogenic degradation. Microbiology and Molecular biology reviews. 61(2):262-280. http://dx.doi.org/10.1007/3-540-28221-1 1

Schnurer, A., Schink, B. \& Svensson, B. H. (1996). Clostridium altunense sp. nov., a mesophilic bacterium oxidizing acetate in syntrophic association with a hydrogenotrphic methanogenic bacterium. International Journal of Systematic Bacteriology; 46:1145-1152. http://dx.doi.org/10.1099/00207713-46-4-1145

Soto, M., Mendez, R. \& Lema, J. M. (1993). Methanogenic and nonmethanogenic activity tests: theoretical basis and experimental setup. Water research; 27:1361-1376. http://dx.doi.org/10.1016/0043-1354(93)90224-6

Stanier, R. Y. \& Niel, C. B. V. (1962). The concept of a bacterium. Archives of Microbiology; 42:17-35. http://dx.doi.org/10.1007/bf00425185

Steritt, R.M. \& Lester, J.N. 1980. Interaction of heavy metals with bacteria Science and Total Environment; 14(1):5-17. http://dx.doi.org/10.1016/00489697(80)90122-9

Taconi, K. A., Zappi, M. E., French, W. T. \& Brown, L. R. (2008). Methanogenesis under acidic conditions ina semi-continuous reactor system. Bioresource Technology: $8075-81$ http://dx.doi.org/10.1016/j.biortech.2008.03.068

Taherzadeh, M. J. \& Karimi, K. (2007). Acid-based hydrolysis processes for ethanol from lignocellulosic materials: A review. BioResources Technology, 2(3):472-499.

Takashima, M. \& Speece, R. E. (1989). Mineral nutrient requirements for high rate methane fermentation of acetate at low SRT. Research Journal of Water Pollution and Control Fedaration; 6(11-12):1645-1650.

Tchobanoglous, G., Theisen, H. \& Vigil, S., (1993). Intergratrated waste management: Enginneering Principles and Management Issues. McGraw-Hill, New York. http://dx.doi.org/10.1177/026921639300700424

Theather, M. R. \& Wood, P. J. (1982). Use of congo red - Polysaccharide interaction in enumeration and characterization of cellulolytic bacteria from bovine rumen. Applied and Environmental Micrology;43(4):777-780.

Valee, B. L. \& Ulner, D.D. (1972). Biochemical efffecs of mercury, cadmium, and lead. Annual Review Biochemistry; 41:91-128. http://dx.doi.org/10.1146/annurev.bi.41.070172.000515

Veeken, A., \& Hamelers, B. (2000). Effects of substrate-seed mixing and leachate recirculation solid state digestion of biowasste. Water Science and Technology; 41(3):255-262.

Venkata M. S., Lalit Babi, V \& Sarma, P. N. (2008). Effects of various pretreatment methods on anaerobic mixed microfora to enhance biohydrogen production utilizing dairy wastewater as substrate. Bioresource Technology; 99:59-67. http://dx.doi.org/10.1016/j.biortech.2006.12.004

Vindis, P., Murse, B., Janzekovic, M. \& Cus, F. (2009). The impact of mesophilic and thermophilic anaerobic digestion on biogas production. Journal of Achivements in Materials and Manufacturing Engineering; 36(2):192198. http://dx.doi.org/10.2507/daaam.scibook.2009.27

Volker, M. (2003). Energy Conservation in acetogenic bacteria. Applied and $\begin{array}{ll}\text { Environmental } & \text { Microbiology; } \\ \text { 69(11):6345-6353. }\end{array}$ http://dx.doi.org/10.1128/aem.69.11.6345-6353.2003

Walker, L., Charles, W. \& Cord-Ruwisch, R. (2009). Comparison of static vessel composting of MSW with anaerobic digestion and the combinations of the two processes. Bioresources Technology; 100: 3799-3807. http://dx.doi.org/10.1016/j.biortech.2009.02.015

Weng, C. N. \& Jeris, J. S. (1976). Biochemical mechanism in the methane fermentation of glutamine and oleic acids. Water Research; 10:918. http://dx.doi.org/10.1016/0043-1354(76)90151-2

Wieringa, K. T. 1936. About the disappearance of hydrogen and carbondioxide under anaerobic conditions. Antony Von Leeuwenhoek; 3:263-273 http://dx.doi.org/10.1007/bf02059556
Wilderer, C. O., Angerhofer, P. A. \& Faulstich, R. M. (2000). Mathematical modeling of the hydrolysis of anaerobic processes. Water Science and Technology; 41:61-69.

Wilson, P. (2004). Anaerobic treatment of agricultural residues and waste water. Doctoral Dissertation. Department of Biotechnology. Lund University, Sweden. Xialing, L., He, L., Jinhuan, C., Guochenh, D. \& Jian, C. (2008). Enhancement and solubilization and acidification waste activated sludge by pretreatment.

Waste Management;

28(12):2614

2622. http://dx.doi.org/10.1016/j.wasman.2008.02.001

Yadavika., Santosh., Sree Krishnan, T. R., Sangeetha, K. \& Vineet, R. (2004) Enhancement of biogas production from solid substrates using different techniques - A Review. Bioresource Technology; 95:1-10. http://dx.doi.org/10.1016/j.biortech.2004.02.010

Yebo Li., Stephen,Y.P. \& Jiying Zhu. (2011). Solid state anaerobic digestion for methane production from organic waste. Renewable and Sustainable Energy Review; 15(1): 821-826. http://dx.doi.org/10.1016/j.rser.2010.07.042

Yen, H-W. \& Brune, D. E. (2007). Anaerobic co-digestion of algal sludge and waste paper to produce methane. Bioresource Technology; 98: 130134. http://dx.doi.org/10.1016/j.biortech.2005.11.010

Young, L. Y. \& Frazer, A. C. (1987). The fate of lignin and lignin derived compounds in anaerobic environment. Geomicrobiology Journal; 5:261293. http://dx.doi.org/10.1080/01490458709385973

Yu, Q., Lei H. Y., Li, Z., Li, H. L., Chen, K. \& Zhang, X .H. (2010). Physical and Chemical properties of waste-activated sludge after microwave treatment Water Research:

http://dx.doi.org/10.1016/j.watres.2009.11.057

Yuan, H. V., Chen, Y. G., zhang, H. X., Jiang, S., Zhou, Q. \& Gu, G.W. (2006) Improved bioproduction of short chain fatty acids (SCFA's) from excess sludge under alkaline conditions. Environmental Science and Technology; 40(6): 2025 2029.

http://dx.doi.org/10.1021/es052252b

Zaid, I., Stephane, G. \& Will, V. (1986). Sulfate reduction relative to methane production in High-Rate anaerobic digestion: Microbiological aspects. Applied and Environmental Microbiology; 51(3): 580-587.

Zayed, G. \& Winter, J. (2000). Inhibition of methane production from whey by heay metals-protective effect of sulfide. Applied Micobiology and biotechnology; 53:726-731. http://dx.doi.org/10.1007/s002530000336

Zinder, S. H. (1990). Conversion of acetic acid to methane by thermophiles. FEMS Microbiology Letters; 75(2-3):125-137. http://dx.doi.org/10.1111/j.1574 6968.1990.tb04090.x 